\title{
STATE STRATEGY OF MOTHERS AND CHILDREN HEALTHCARE IN UKRAINE AS A MECHANISM FOR ACHIEVING SUSTAINABLE DEVELOPMENT GOALS
}

\author{
Mariya Malachynska ${ }^{1}$ \\ ${ }^{1}$ Postdoctoral student, Odessa Regional Institute for Public Administration of the National Academy for \\ Public Administration under the President of Ukraine, Odessa, Ukraine, e-mail: malaschynska@ukr.net. \\ ORCID: https://orcid.org/0000-0003-2895-3666
}

\begin{abstract}
The analysis of the state strategy on reproductive health of the population in Ukraine is conducted. The purpose of the study is to analyze the state strategy for improving reproductive health of population in Ukraine, especially the protection of mothers and children, as an important component of overall health, which significantly affects the demographic situation and ensuring the socio-economic development of the country. The study has a descriptive design that set out a framework for a systematic search of literature. Four main tasks were defined for conducting a thorough analysis: to form a clear vision of the state strategy for maternal and child health in Ukraine; to analyse normative-legal acts that allow to implement the state policy in the field of reproductive health; to analyse the state of development of the reproductive health system and identify possible ways to solve problems. The mothers and children healthcare is regarded as an important component of general health, which significantly affects the demographic situation and ensuring the socio-economic development of the country. Despite the implementation of many international technical assistance programs and projects operating in Ukraine, the situation in the field of reproductive health has not been significantly improved yet. In the absence of a new State Program and Action Plan in the field of reproductive and sexual health Ukraine's previous achievements in this area may be lost and Ukraine may be threatened with non-fulfilment of its international obligations in this area.
\end{abstract}

Keywords: mothers and children healthcare, state strategy, sustainable development goals, COVID-19, reproductive health of population.

JEL Classification: H51, I11

Formulas:0; fig.3; tabl. 0; bibl. 30

Introduction. The main driving force of the country's sustainable development is its population. Therefore, many long-term social prospects are based on demographic processes. Demographic hardship in Ukraine increases the importance of reproductive health to ensure the reproduction of the population, as it is an integral part of the health of the nation as a whole and is of strategic importance for sustainable development of societyю

In line with the United Nations Millennium Development Goals, which have been changed by the Sustainable Development Goals, and the World Health Organization strategy, one of the priorities in the field of reproductive health for the European region is safe motherhood and reducing infant mortality [14], [16].

However, the state of reproductive health in Ukraine is of particular concern. Children's health is directly related to women's health, which has a steady tendency to deteriorate, as evidenced by the increase over the past ten years in the incidence of anemia in pregnant women, diseases of the genitourinary system and circulatory system. The number of infertile marriages and newborns with congenital pathology is increasing. 
The current capacity of the health service alone cannot provide a quality level of care for pregnant women and women in labor at this stage. Therefore, the goals of sustainable development can be achieved through government regulation aimed at addressing organizational and personnel issues in the medical field [11]. It is especially important to find ways to solve this problem at the regional level, taking into account the territorial characteristics of demographic processes, infrastructure of the health care system, etc.

Literature review. The study of the development of the reproductive health system in Ukraine is mostly conducted by Ukrainian scientists who work in two key areas: the formation of state reproductive health policy and its implementation in the context of health care reform; ensuring the quality, efficiency and timeliness of medical services at the level of the medical institution. An analysis of a large body of research suggests that managerial approaches to both maternal and child health policymaking and governance at the health care institution level need to change. Regulations in this direction need to be significantly improved.

Recognizing the strategic importance of reproductive health for the sustainable development of society, Ukraine approved the Action Program of the International Conference on Population and Development (Cairo, 1994) [7], the United Nations Millennium Development Goals (2000-2015), the Sustainable Development Plan and Goals (2016-2030). These strategic documents became the basis of the state policy in the field of preserving and maintaining the reproductive health of the population. Since 1995, national programs (Family Planning 1995-2000 and Reproductive Health 2001-2005) and the state program Reproductive Health have become political and strategic tools for the implementation of international documents on solving the problems of reproductive health of the population of Ukraine [13]. Health of the Nation until 2015", based on the WHO Regional Strategy for Sexual and Reproductive Health (2001) [15].

Aims. The purpose of the study is to analyze the state strategy for improving reproductive health of population in Ukraine, especially the protection of mothers and children, as an important component of overall health, which significantly affects the demographic situation and ensuring the socio-economic development of the country.

Methods. The study has a descriptive design that set out a framework for a systematic search of literature. Four main tasks were defined for conducting a thorough analysis: to form a clear vision of the state strategy for maternal and child health in Ukraine; to analyse normative-legal acts that allow to implement the state policy in the field of reproductive health; to analyse the state of development of the reproductive health system and identify possible ways to solve problems [3-5].

Results. The results of the analysis of population changes over the last 10-15 years show that Ukraine is in a state of deep demographic crisis due to depopulation, increasing the share of the elderly and reducing life expectancy. This has a negative impact on the development of productive forces, the level of welfare of people and the economic situation in the country and, accordingly, raises the issue of reproduction of a healthy population and stimulating the birth rate. 
In Ukraine, after a long period of increasing fertility (2002 - 2012), since 2013 there has been a decrease. It became especially noticeable in 2020 (Fig.1), when the number of births decreased compared to 2012 by more than 220 thousand people (or $43.6 \%$ ). The number of births is declining every year, in recent years by 10-30 thousand.

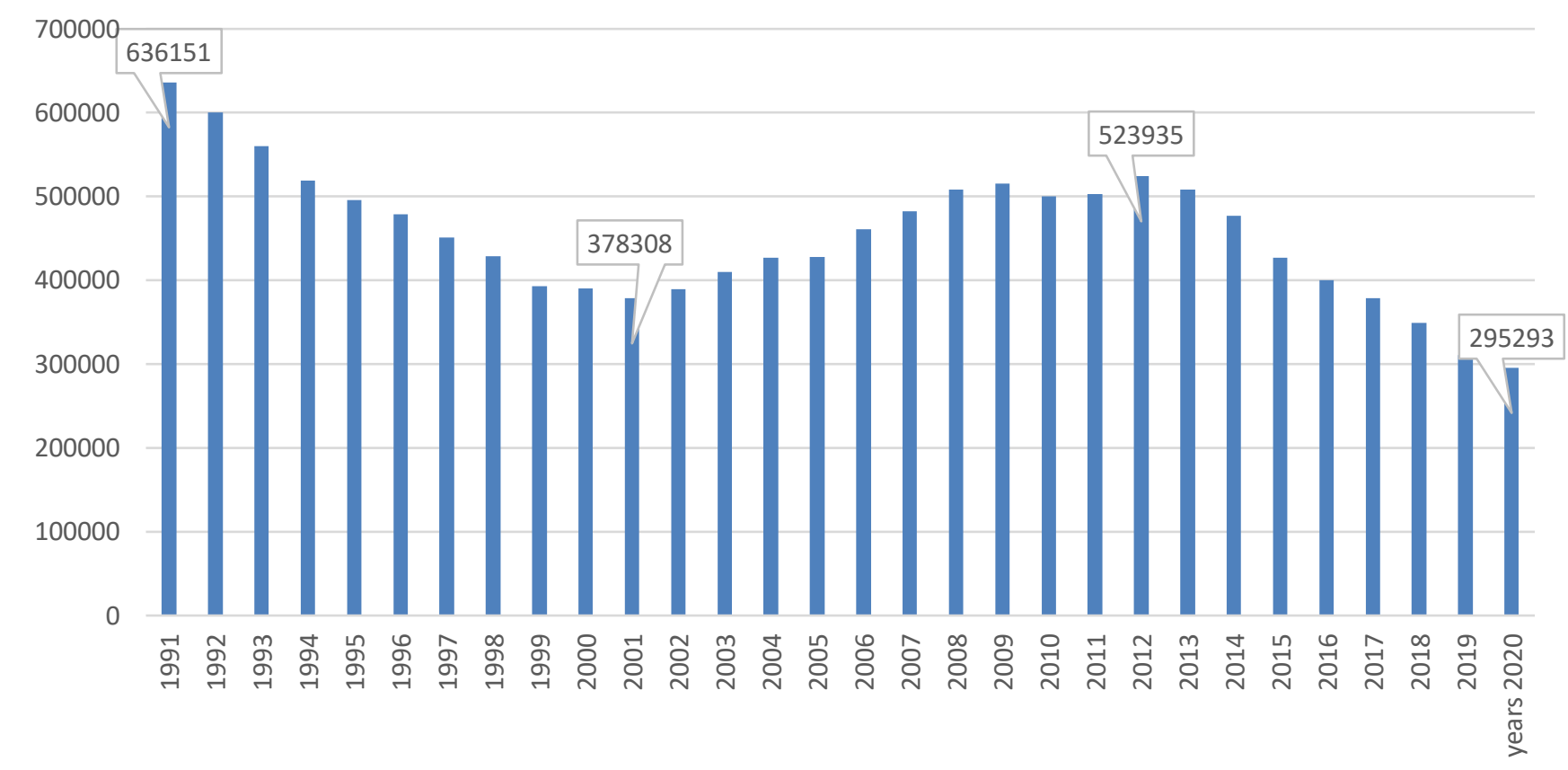

Figure 1. Birth rates in Ukraine for the last thirty years

Source: Ministry of Health of Ukraine [6], [8].

Socio-economic situation caused by crisis and military-political instability also have a negative impact on the current reproductive activity of the population and the health of newborns. Thus, in addition to a significant reduction in the frequency of childbirth, the infant mortality rate remains high. In such conditions, the value of each birth increases, and the preservation of the reproductive health of potential mothers and fathers becomes a national priority for the reproduction of Ukraine's human potential.

Despite the implementation of many international technical assistance programs and projects operating in Ukraine, the situation in the field of reproductive health has not been significantly improved. The level of maternal mortality in Ukraine, as an indicator of socio-economic development of the state, is much higher than the average of the European Union, which requires priority attention to the protection of motherhood and childhood.

Despite the reduction in the epidemic process of HIV infection, the problem of HIV infection has a negative impact on the reproductive health of the population. Risks of HIV spread have increased in the current humanitarian crisis and hostilities in eastern Ukraine. Increasing morbidity in difficult socio-economic and sanitary conditions (especially among internally displaced persons, residents of temporarily occupied territories, conflict zones), likely increase in the prevalence of bad habits, 
risky sexual behavior and gender-based violence in military violence attention and operational decisions of the state.

One of the important indicators of the state of reproductive health is infertility. About 15\% of married couples in Ukraine suffer from infertility, which can be attributed to direct reproductive losses. The level of infertility can be significantly reduced through measures to prevent sexually transmitted infections, postpartum infections, non-use of dangerous methods of abortion. In case of infertility, it is necessary to provide quality counseling, diagnosis and appropriate treatment [10].

The trend of increasing the age of women during marriage and the birth of their first child, the so-called "aging of motherhood", poses new challenges for maintaining the reproductive health of potential mothers and fathers, places higher demands on the health care system benefits for this category of women.

Problems that have arisen in the field of reproductive health of the population of Ukraine are due to many factors: unsatisfactory social status of citizens and insufficient attention to the role of the family; mortality of men of working age, which significantly exceeds the mortality of women; high maternal and infant mortality rates due to lack of public awareness of healthy lifestyles; insufficient level of modern high-tech equipment of health care facilities and training of specialists, which leads to a decrease in the quality of medical care; unsatisfactory state of health of pregnant women, which leads to an increase in complications during childbirth and the emergence of diseases in newborns; high level of abortion; common oncogynecological pathology of the reproductive organs, which is one of the leading causes of death and leads to the loss of a significant number of young women who have not realized their reproductive function [12].

Common factors that continue to negatively affect the reproductive and sexual health of the population of Ukraine and the deterioration of birth rates are: crisis socio-economic situation, falling living standards, increasing stress, lack of social and legal protection in the workplace, lack of proper control over observance of rules and norms of labor protection and safety, deterioration of food quality, growth of general morbidity of the population [9].

This state of affairs necessitates the further implementation of a set of measures aimed at improving the reproductive health of the population.

Ukraine, as a member state of the United Nations, in 2015 approved the Sustainable Development Plan for 2016 - 2030 and related Sustainable Development Goals. Ukraine has reaffirmed its commitment.

Objective 3 - "Ensuring a healthy lifestyle and promoting well-being for all at all ages", in particular:

-Objective 3.1 - to reduce the global maternal mortality rate;

-Objective 3.2 - to end preventable mortality in infants and children under 5 years of age, reduce neonatal mortality

o Task 3.7 - ensure universal access to sexual and reproductive health services, including family planning, information and education, and the integration of reproductive health into national strategies and programs, and Objective 5, 
○ Task 5.6 - ensure full respect for sexual and reproductive rights, in accordance with the Program of Action of the International Conference on Population and Development and the Beijing Platform for Action, as well as the documents containing the results of subsequent review conferences.

In accordance with the Resolution adopted by the General Assembly on 25 September 2015, the 2030 Agenda for Sustainable Development has been set [1] This plan will be implemented by all countries and all stakeholders, acting based on cooperation and partnership. The seventeen Sustainable Development Goals and the 169 challenges we proclaim today demonstrate the scale and ambition of this new global Agenda. They focus on the development of the Millennium Development Goals and the completion of tasks that have failed. They aim to realize human rights for all, achieve gender equality and empower all women and girls. They are comprehensive and indivisible and balance the three dimensions of sustainable development: economic, social and environmental.

Strategies and approaches to strengthen the policies of European countries in this area are also set out in the WHO European Action Plan for Strengthening Sexual, Reproductive Health and Rights for 2017-2021.

Although there are currently no accurate data on the effects of COVID-19 on pregnancy and women's reproductive health, foreign surveys and studies have shown that the COVID-19 pandemic is a period of heightened alert among both professionals and the general public [2].

Increasing the risk of maternal and child morbidity, as well as mortality, mental disorders, and disruptions in sexual and reproductive health services are the few problems that any woman in the world can face today. In Ukraine, 5.9\% of the total number of cases are children under 17 years of age and $0.1 \%$ - pregnant women (Figures 2-3).

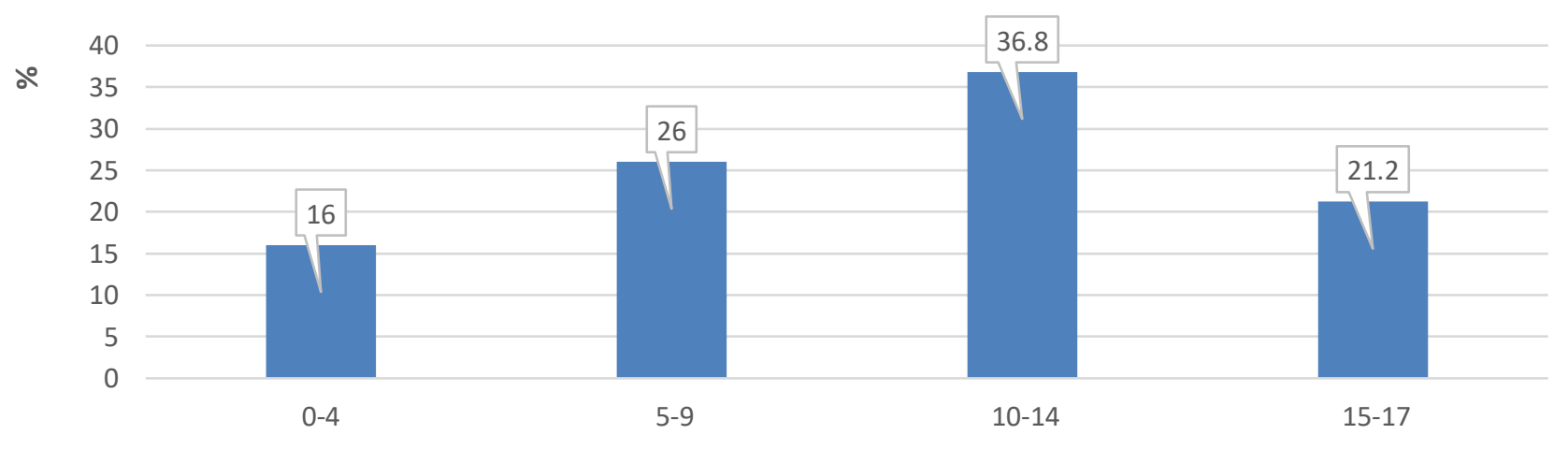

age

Figure 2. Age groups of children infected with COVID-19 under 17 years of age Source: Ministry of Health of Ukraine [6].

At present, Ukraine does not have a comprehensive state program at the national level, which defines the directions and tasks of solving problems in the field of reproductive health. Therefore, there are three possible solutions to the problem. 


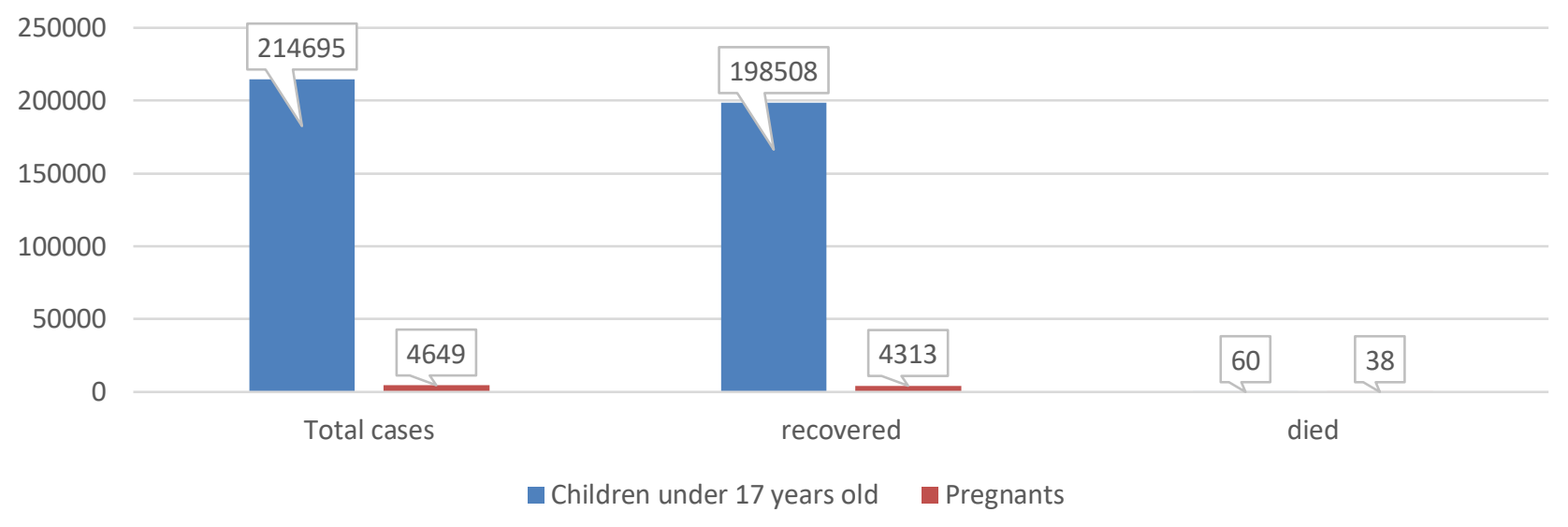

Figure 3. Information on children under 17 and pregnant women with COVID19 in Ukraine as of December 19, 2021

Source: Ministry of Health of Ukraine [6].

The first option is the lack of a strategy and a state program for the preservation of reproductive and sexual health. This threatens the sustainability of the results of the previous program and does not respond to the new challenges posed by the deep socio-economic and humanitarian crisis [17-19]. The result of such an approach will be the deterioration of the health of citizens, further reproductive losses and the consolidation of persistent negative trends in the medical and demographic situation in the country. In the long run, this will require a significant increase in health care expenditures without a significant improvement in the reproductive and sexual health of the population, maternal and infant morbidity and mortality rates.

The second option is to continue financing certain areas and items of expenditures provided for in the previous program, mostly aimed at overcoming critical conditions and complications in the process of providing specialized medical care. Not taking into account the peculiarities of the situation in the country, modern global approaches to improving reproductive health and sex education, lack of a systematic cross-sectoral approach to strengthen the preventive component and screening programs, insufficient integration of reproductive and sexual health services in primary care. health care will have negative consequences [20-22]. This will lead to an increase in morbidity, late detection of complications, which will require significant financial resources to provide highly specialized medical care and further medical and social support of the child and possibly the mother throughout life.

The third option is the adoption of a new State Program on Reproductive and Sexual Health with secured funding. This approach demonstrates the consistency of the state's efforts to fulfill its interstate commitments [23-30]. Measures with proven effectiveness are aimed at prevention, increase the motivation of the population, especially adolescents and young people to a healthy lifestyle, safe sexual behavior and reproductive health. This will reduce the need for medical care. Strengthening the system of early diagnosis and treatment of diseases, control over the course and prevention of complications, especially during pregnancy and childbirth will help reduce the incidence of critical conditions, primary disability, maternal and infant 
mortality. This approach will ensure the rational use of industry resources, improve the quality and efficiency of health care.

The third, optimal option will be to overcome inequalities in access to information and quality services in the field of reproductive and sexual health at all stages of life and will ensure the right of everyone to have the highest attainable standard of health. The program should ensure the continuity of care and the principle of covering all stages of human life, taking into account gender aspects. Creating mechanisms for strategic management, sustainable intersectoral cooperation, strengthening accountability and involving the public and international organizations will ensure the effectiveness and efficiency of the Program.

Conclusions. The best way to solve the problems of reproductive and sexual health is to develop and implement the National Program "Reproductive and Sexual Health of the Nation until 2021", taking into account the achievements of the National Program "Reproductive Health of the Nation" until 2015.

In the absence of a new State Program and Action Plan in the field of reproductive and sexual health, Ukraine's previous achievements in this area may be lost and Ukraine may be threatened with non-fulfillment of its international obligations in this area.

To solve the problem some activities are needed:

-developing and implementing measures aimed at the formation of reproductive and sexual health of the population through the promotion of healthy lifestyles, responsible parenting, culture of relationships and family values, starting a family, planning the birth of a healthy child.

-reviewing and improving the regulatory framework for reproductive and sexual health to ensure compliance with the internationally recognized best evidence base.

-developing strategies and mechanisms for organizing population screening programs for the prevention and early diagnosis of cancer of the reproductive organs in women and men.

-providing effective mechanisms for program management, monitoring and evaluation of results.

Improving health indicators, which is a prerequisite for positive dynamics of demographic processes and sustainable development, requires strong intersectoral cooperation of all government agencies and institutions, cooperation of public and international organizations and the private sector involved in public policy in sexual and reproductive health.

\section{References:}

1. General Assembly (2015). Resolution adopted by the General Assembly on 25 September 2015. URL: https://www.ua.undp.org/content/ukraine/uk/home/library/sustainable-development-report/the-2030-agenda-forsustainable-development.html

2. Kalashnyk, N., \& Khudoba, O. (2021). COVID-19 Challenges over Mental Health Public Policy. BRAIN. Broad Research in Artificial Intelligence and Neuroscience, 11(2Sup1), 165-174.

3. Karpa, M (2021). Peculiarities of regulating the activity of public authorities in the conditions of constitutional changes: on the example of the system of judicial authorities. AD ALTA: Journal of Interdisciplinary Research, Czech Republic. Volume 11, Issue 2. 60-67.

4. Karpa, M. (2021). Features of introduction of the system approach to the state policy. Karpa M., Akimov O. Public Administration and Law Review, FEATURES OF INTRODUCTION OF THE SYSTEM APPROCH TO THE STATE POLICY. Karpa, M., Akimov, O., \& Akimova, L. Public Administration and Law Review, (3), 1117. https://doi.org/10.36690/2674-5216-2021-3-11 
5. Karpa, M. (2021). The competence of the executive authorities of Ukraine in the field of healthcare and national security to eliminate the consequences of coronavirus disease (Covid-19). Karpa M., Akimov O. Public Administration and Law Review, Issue 1 (5), 2021, pp. 73-82. https://doi.org/10.36690/2674-5216-2021-1

6. Mykychak I. (2021). Status and prospects of development of motherhood and childhood protection to ensure demographic sustainability of Ukraine: meeting of the Board of the Ministry of Health. December 21, 2021, Lutsk 7. Report of the International Conference on Population and Development. Cairo 5-13 September 1994. URL: https://www.unfpa.org/sites/default/files/event-pdf/icpd_eng_2.pdf

8. State Statistics of Ukraine. URL: http://www.ukrstat.gov.ua

9. The Cabinet of Ministers of Ukraine (2006). On approval of the State Program "Reproductive Health of the Nation" for the period up to 2015: Resolution, December 27, 2006 № 1849. URL: https://zakon.rada.gov.ua/laws/show/18492006-п\#Text

10. The Cabinet of Ministers of Ukraine (2006). The concept of the state program "Reproductive Health of the Nation for 2006-2015: Order, April 27, 2006, №244-r. URL: https://www.kmu.gov.ua/npas/35202731

11. The Cabinet of Ministers of Ukraine (2021). On approval of the Government's priority action plan for 2021: Order, March 24, 2021 № 276-r URL: https://zakon.rada.gov.ua/laws/show/276-2021-p\#Text

12. The concept of the national program "Reproductive and sexual health of the nation until 2021": a draft order of the

Cabinet of Ministers of Ukraine. URL: https://www.apteka.ua/article/404360

13. The Ministry of Health of Ukraine (2013). On Improving the Family Planning and Reproductive Health System in Ukraine: Order, 29.11.2013 № 1030/102. URL: https://zakon.rada.gov.ua/laws/show/z2162-13\#top

14. United Nations Population Fund (2019). Sexual and Reproductive Health and Rights: An Essential Element of Universal Health Coverage: URL: https://www.unfpa.org/publications/sexual-and-reproductive-health-and-rights-essential-elementuniversal-health-coverage

15. World Health Organization (2001).WHO regional strategy on sexual and reproductive health. URL: https://www.euro.who.int/_data/assets/pdf_file/0004/69529/e74558.pdf

16. World Health Organization (2004). Reproductive health strategy to accelerate progress towards the attainment of international development goals and targets Global strategy adopted by the 57th World Health Assembly. URL: https://www.who.int/reproductivehealth/publications/general/RHR_04_8/en/

17. Karpa, M (2021). Competence Approach to the Development of Modern Public Administration: Theory and Practice of Implementation. International Conference on Economics, Law and Education Research (ELER 2021). pp. 40-45. doi: https://doi.org/10.2991/aebmr.k.210320.008.

18. Karpa, M. (2021). Universally recognized and national principles of competence of civil servants as a basis for legal provision of information security: the experience of the European Union. Journal of interdisciplinary research (11(2)). pp. 48-53.

19. Karpa, M. (2020). Implementation of innovative forms and models of public administration in the sphere of culture in Ukraine / Karpa, M., O. Akimov, and V. Shykerynets / Karpa, M., O. Akimov, and V. Shykerynets / Public Administration and Law Review, no. 3, Oct. 2020, pp. 13-24, doi:10.36690/2674-5216-2020-3-13.

20. Gupta, S.K., Alareeni, B., Karpa, M.I., Umrao, L.S., \& Gupta, M. (2021). Detection of Fake News Problems and Their Evaluation Through Artificial Intelligence. Lecture Notes in Networks and Systems, 2021, 194 LNNS. pp. 94-101. 21. Mlaabdal, S., Chygryn, O., Kwilinski, A., Muzychuk, O., \& Akimov, O. (2020) Economic Growth and Oil Industry Development: Assessment of the Interaction of National Economy Indicators. Proceedings of the 36th International Business Information Management Association (IBIMA). pp. 8102-8114.

22. Gupta, M., Alareeni, B., Akimova, L., Gupta, S.K., \& Derhaliuk, M.O. (2021) Application of Fuzzy Logic Data Analysis Method for Business Development. Lecture Notes in Networks and Systems, 2021, 194 LNNS. pp. 75-93.

23. Pustova, N. and Akimov, O. (2021), Child labor and public administration policy against its use, Investytsiyi: praktyka ta dosvid, vol. 20, pp. 81-86. DOI: 10.32702/2306-6814.2021.20.81.

24. Akimov, O. (2020), Systemogenesis of personal competences in psychogenic measurement, Investytsiyi: praktyka ta dosvid, vol. 5-6, pp. 81-88. DOI: 10.32702/2306-6814.2020.5-6.81.

25. Akimov, O. (2020), Substantiation of the paradigm of the systemogenesis of public administration, Investytsiyi: praktyka ta dosvid, vol. 4, pp. 86-92. DOI: 10.32702/2306-6814.2020.4.86.

26. Akimov, O. (2020), Tendencies of development of public-service activity as the bases of the paradigm of the systemogenesis of public administration, Investytsiyi: praktyka ta dosvid, vol. 3, pp. 135-142. DOI: 10.32702/23066814.2020.3.135.

27. Akimov, O. (2019), System-genesis approach to the implementation of public administration in Ukraine: problems of formation, Investytsiyi: praktyka ta dosvid, vol. 21, pp. 90-95. DOI: 10.32702/2306-6814.2019.21.90.

28. Akimov, O. (2019), The robustness of the system of professional activity of public employees: systemogenescial context, Investytsiyi: praktyka ta dosvid, vol. 5, pp. 104-109. DOI: 10.32702/2306-6814.2019.5.104.

29. Akimov, O. (2018), Functional factors of the system genesis of the professional activities of civil servants, Investytsiyi: praktyka ta dosvid, vol. 24, pp. 68-74. DOI: 10.32702/2306-6814.2018.24.68.

30. Akimov, O. (2018), The concept of the system genesis of the professional activities of public servants, Investytsiyi: praktyka ta dosvid, vol. 23, pp. 133-138. DOI: 10.32702/2306-6814.2018.23.133.

Received: November 18, 2021

Approved: December 24, 2021 